\title{
Effect of Sorghum Based Nutritional Programs on Performance, Carcass Yield and Composition of Breast in Broilers
}

mAuthor(s)

\author{
Silveira $\mathrm{MM}^{\prime}$ \\ Martins JMS" \\ Litz FIII \\ Carvalho CMC III \\ Moraes CA"II \\ Silva MCA"II \\ Fernandes $\mathrm{EA}^{\mathrm{IV}}$
}

Doutoranda do Programa de Pós-Graduação em Genética e Bioquímica da Universidade Federal de Uberlândia-INGEB/UFU.

" Doutoranda do Programa de Pós-Graduação em Zootecnia da Escola de Veterinária e Zootecnia da Universidade Federal de Goiás-UFG

III Doutoranda do Programa de Pós-Graduação em Ciências Veterinárias da Universidade Federal de Uberlândia-UFU.

Iv Docente da Faculdade de Medicina Veterinária da Universidade Federal de Uberlândia-UFU.

\section{ABSTRACT}

An experiment was conducted to compare three nutritional programs, which were developed with tannin-free grain sorghum based diets, evaluating performance, carcass yield and bromatological composition of the pectoral muscle of broilers. A total 1360 chicks mixed (50:50), from one to 42 days old Hubbard Flex Broilers, were housed in a completely randomized design consisting of treatments and 10 replicates each, distributed as follows: three programs with whole sorghum grain based diets (nutritional program with daily adjustment, nutritional program with every three days adjustment and nutritional program with four stages and a program with ground and whole sorghum grain based feed (four stages). The cumulative performance was evaluated at, 21 and 42 days, determining feed intake, weight gain, feed conversion and viability. At 42 days, the yield of eviscerated carcass, breast (full and boneless), thighs/drumsticks and wings and breast composition were evaluated. Nutritional adjustments showed better feed conversion, did not affect the carcass, commercial cuts yield and had a good breast meat quality. It can be concluded that daily feed programs could be performed in poultry industry with the mixture of whole sorghum grains and concentrates directly on farms contributing to better logistics and feed transportation cost.

\section{INTRODUCTION}

The most important ingredient used in bird's feed is the corn, which accounts for $60 \%$ to $70 \%$ of the total formulations cost, occupying a prominent position on the production's final cost. However, once it is a commodity, its price is subjected to foreign exchange and market prices, which may cause imbalance in the input of internal supply and change the product purchasing strategy, which aims to reduce costs and increase profits (Moura et al., 2010).

This has estimulated interests for searching alternative ingredients for livestock activities which are highly dependent on this input, not affecting the bird's performance (Santos et al., 2006). According to Carolino et al. (2014), among the researched options, the one that most closely matches the nutritional characteristics of the corn is sorghum (Sorghum bicolor, L. Moench). The cost of the sorghum grain is between $70 \%$ and $80 \%$ of corn grain and technically can replace up to $100 \%$ of corn in broilers (Fernandes et al., 2002; Garcia et al., 2005; Rocha et al., 2008; Garcia et al., 2013) and layers (Moreno et al., 2007; Assuena et al., 2008) diets, not affecting performance.

A possibility with the sorghum usage is to provide it as whole grain without the need for grinding (Fernandes et al., 2013), resulting in feed cost reduction, because according to Dozier (2002) the cost of cereal grinding represents $25 \%$ to $30 \%$ of the feed production cost. Besides this important economic advantage, feeding with the whole grain is 
Silveira MM, Martins JMS, Litz F, Carvalho CMC, Moraes CA, Silva MCA, Fernandes EA
Effect of Sorghum Based Nutritional Programs on Performance, Carcass Yield and Composition of Breast in Broilers part of an alternative nutritional strategy. It has several potential advantages: provides an environmental enrichment for birds (Picard et al., 2002) since they prefer larger particles (Xu et al., 2015), stimulates gizzard muscle development and increases the enzymatic digestion (Macleod, 2013).

Feeding programs correspond to the use of different feeding management practices in broiler feed at different development stages or periods. The programs commonly used for broiler production in Brazil follow the recommendations of Rostagno et al. (2011) in which four different diets and each phase are recommended (pre-starter, starter, grower and finisher) until 42 days old.

The chickens nutritional requirements have traditionally been established through experiments in which there is the addition of a limiting nutrient in the diet while keeping the others at appropriate levels. The nutrient level that maximizes the weight gain and/ or feed efficiency is considered the requirement for the study phase (Buteri, 2003; Rostagno et al., 2007; Sakomura e Rostagno, 2007; Rostagno et al., 2011). These established levels correspond to the requirement average value for the evaluated phase, this means that in the starting phase birds receive a sub-optimal nutrient and in the ending phase, they receive an excessive one.

The solution presented for this nutritional impasse has been the recommendation of the adoption of a greater number of diets during the life cycle of birds, known as multiple feeding program ("phase-feeding"), where the differences between the required and the supplied would be lower (Tavernari et al., 2009).

Therefore, in order to ensure greater profitability, it has been recommended to use daily feeding programs, which is still impossible at the level of the poultry industry, but new technologies will possibly be created in the future (Tavernari et al., 2009). This study aimed to compare three nutritional programs, which were developed with tannin-free grain sorghum based diets, evaluating performance, carcass yield and bromatological composition of the pectoral muscle of broilers.

\section{MATERIAL AND METHODS}

\section{Local and Performing Period}

The study was performed in experimental conventional open house, at Glória Farm in Federal University of Uberlândia (UFU), located in Uberlândia, Minas Gerais, from march to april 2013, according to ethical rules approved by Committee of Ethics in Animal Studies - CEUA - UFU with research protocol number 030/13.

\section{Birds and Experimental Delineation}

A 1360 commercial line Hubbard Flex broiler chicks, from one to 42 days of age, were mixed (50:50) and housed, from one to 42 days old, with initial body weight of $44 \mathrm{~g} \pm 2 \mathrm{~g}$. They were provided by a poultry company in the city of Uberlândia, Minas Gerais. The chicks were vaccinated against Marek and Gumboro disease in the hatchery.

The experiments were conducted in a completely randomized design consisting of four treatments: daily nutritional adjustments program by mixing feed with whole grain sorghum (Daily WS); every three days nutritional adjustments program by mixing feed with whole grain sorghum (3 days WS); nutritional program of four stages with whole sorghum grain (4 stages WS); and nutritional program of four stages with ground sorghum grain (4 stages GS). Each treatment had 10 replications (pens) and 34 mixed birds (50:50) each, amounting 40 experimental units.

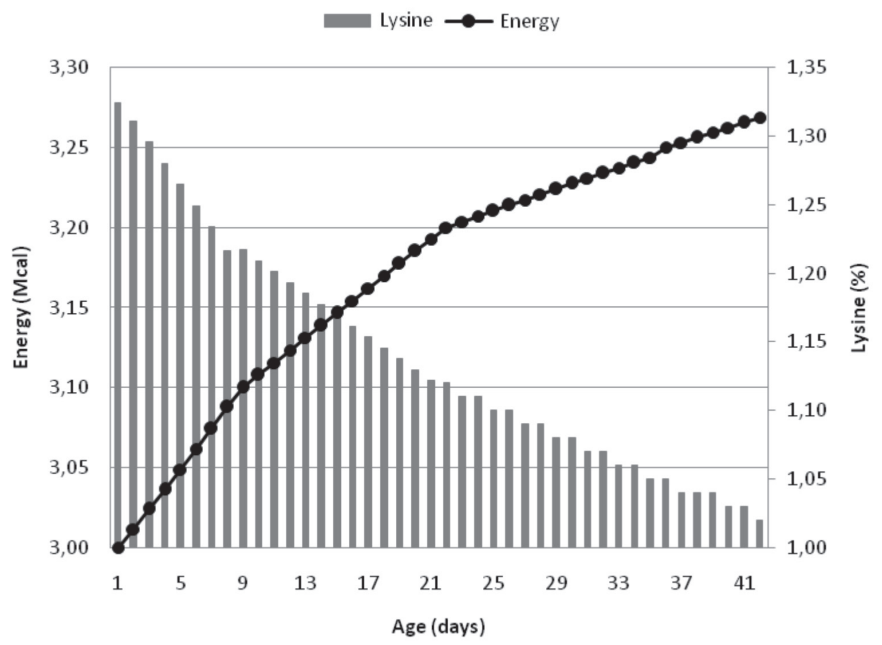

Figure 1 - Metabolisable energy (Mcal) and digestible lysine (\%) levels in the daily nutritional progam according to broilers age.

The diets were formulated in order to meet the broilers nutritional requirements, based at nutritional program recommendation by Rostagno et al. (2011). The nutritional and energy levels, as well as the feed composition of the diets involved in all treatments were based on the four nutritional stages (Table 1).

In the daily adjustment nutritional program (Daily WS), the diets were prepared according to the following protocol:

Nutritional levels: From one to eight days old, the ration of the first day was formulated with pre-starter 
Table 1 - Ingredient's nutritional composition calculated e analyzed in the experimental diets.

\begin{tabular}{|c|c|c|c|c|}
\hline \multirow{2}{*}{ Ingredients (\%) } & Pre-starter & Starter & Grower & Finisher \\
\hline & 1 to 8 days & 9 to 21 days & 22 to 35 days & 36 to 42 days \\
\hline Sorghum grain $8.8 \% \mathrm{CP}$ & 53.43 & 55.27 & 57.67 & 60.55 \\
\hline Soybean meal $46.5 \%$ CP & 37.18 & 34.57 & 31.38 & 28.67 \\
\hline Soybean oil & 5.09 & 6.31 & 7.44 & 7.67 \\
\hline Phosphate & 1.85 & 1.50 & 1.28 & 1.05 \\
\hline Limestone & 0.92 & 0.94 & 0.89 & 0.79 \\
\hline $\mathrm{NaCl}$ & 0.46 & 0.47 & 0.44 & 0.45 \\
\hline DL-Methionine & 0.22 & 0.17 & 0.16 & 0.19 \\
\hline L-Lysine & 0.33 & 0.28 & 0.26 & 0.26 \\
\hline L-Threonine & 0.13 & 0.09 & 0.08 & 0.07 \\
\hline Initial Premix ${ }^{1}$ & 0.40 & 0.40 & 0.00 & 0.00 \\
\hline Growth Premix ${ }^{2}$ & 0.00 & 0.00 & 0.40 & 0.00 \\
\hline Final Premix ${ }^{3}$ & 0.00 & 0.00 & 0.00 & 0.30 \\
\hline Total & 100 & 100 & 100 & 100 \\
\hline \multicolumn{5}{|l|}{ Composition Calculated } \\
\hline Metabolizable energy (kcal/kg) & 3,000 & 3,100 & 3,200 & 3,250 \\
\hline Crude protein (\%) & 22.56 & 21.36 & 20.08 & 19.01 \\
\hline Calcium (\%) & 0.92 & 0.84 & 0.76 & 0.66 \\
\hline Available phosphorum (\%) & 0.47 & 0.40 & 0.35 & 0.31 \\
\hline Sodium (\%) & 0.22 & 0.22 & 0.21 & 0.21 \\
\hline Digestible Methionine (\%) & 0.67 & 0.61 & 0.57 & 0.42 \\
\hline Digestible Methionine+ Cystine (\%) & 0.95 & 0.88 & 0.83 & 0.77 \\
\hline Digestible Lysine (\%) & 1.32 & 1.22 & 1.13 & 1.06 \\
\hline Digestible Threonine (\%) & 0.86 & 0.79 & 0.74 & 0.69 \\
\hline Digestible Arginine (\%) & 1.40 & 1.32 & 1.22 & 1.15 \\
\hline Digestible Tryptophan (\%) & 0.23 & 0.24 & 0.20 & 0.19 \\
\hline Digestible Valine (\%) & 0.94 & 0.90 & 0.85 & 0.81 \\
\hline Chlorine (\%) & 0.28 & 0.29 & 0.27 & 0.28 \\
\hline Potassium (\%) & 0.86 & 0.81 & 0.76 & 0.72 \\
\hline \multicolumn{5}{|l|}{ Composition Analyzed } \\
\hline Crude energy (kcal/kg) & 4,088 & 4,274 & 4,380 & 4,430 \\
\hline Crude protein (\%) & 22.60 & 21.25 & 20.10 & 19.00 \\
\hline Calcium (\%) & 0.92 & 0.85 & 0.75 & 0.67 \\
\hline Total phosphorum (\%) & 0.67 & 0.60 & 0.56 & 0.50 \\
\hline Mineral matter (\%) & 5.20 & 5.19 & 5.16 & 5.15 \\
\hline Dry matter (\%) & 90.30 & 91.61 & 91.07 & 91.42 \\
\hline Ether extract (\%) & 3.50 & 3.68 & 3.83 & 4.00 \\
\hline
\end{tabular}

'Initial Premix (composition per kg of product): Vitamin A 1600000.00 Ul; Vitamin B1 600.00 mg; Vitamin B12 2000.00 mcg; Vitamin B2 800.00 mg; Vitamin B6 400.00 mg; Vitamin D3 $400000.00 \mathrm{Ul}$; Vitamin E 3000.00 mg; Vitamin K 400.00 mg; Zinc 12.60 g; Copper 1260.00 mg; Selenium 80.00 mg; Iron 10.50 g; lodine 252.00 mg; Manganese 12.60 g; Folic Acid 140.00 mg; Pantothenic Acid 1600.00 mg; Bacitracin Zinc 11.00 g; Biotin 12.00 mg; Choline 70.00 g; Methionine 336.60 g; Sodium Monensin 22.00 g; Niacin 6000.00 mg,

${ }^{2}$ Growth Premix (composition per kg of product): Vitamin A 1280000.00 Ul; Vitamin B1 400.00 mg; Vitamin B12 1600.00 mcg; Vitamin B2 720.00 mg; Vitamin B6 320.00 mg; Vitamin D3 350000.00 Ul; Vitamin E 2400.00 mg; Vitamin K 300 mg; Copper 1200.00 mg; Iron 10.00 g; lodine 240.00 mg; Manganese 12.00 g; Selenium 60.00 mg; Zinc 12.00 g; Folic Acid 100.00 mg; Pantothenic Acid 1600.00 mg; Biotin 6.00 mg; Choline 50.00 g; Halquinol 6000.00 mg; Methionine 267.30 g; Niacine 4800.00 mg; Salinomycin 13.20 g. ${ }^{3}$ Final Premix (composition per kg of product): Vitamin A $1300260.00 \mathrm{Ul}$; Vitamin B1 $166.00 \mathrm{mg}$; Vitamin B12 1667.00 mcg; Vitamin B2 666.80 mg; Vitamin B6 200.00 mg; Vitamin D3 $400000.00 \mathrm{Ul}$; Vitamin E $2167.10 \mathrm{mg}$; Vitamin K 333.40 mg; Copper 2000.00 mg; Iron $16.60 \mathrm{~g}$; lodine 400.00 mg; Manganese $20.00 \mathrm{~g}$; Selenium 60.68 mg; Zinc $20.00 \mathrm{~g}$; Folic Acid 100.00 mg; Pantothenic Acid 1333.00 mg; Biotin $6.67 \mathrm{mg}$; Choline 50.00 g; Methionine 230.00 g; Niacine 4000.00 mg; Virginiamycin $3666.00 \mathrm{mg}$.

feed levels and in the following days the metabolizable energy levels were increased by the same amount every day, until reaching the initial feed energy level on the $9^{\text {th }}$ day. On the other hand, the levels of all other nutrients were reduced each day until reaching those levels projected for the starter feed at the $9^{\text {th }}$ day. Between 9 to 21 days, the $9^{\text {th }}$ day feed was formulated with starter feed levels and in the following days the metabolizable energy levels were increased by the same amount every day until reaching the growth feed energy level of the $22^{\text {nd }}$ day. On the other hand, the levels of all other nutrients were daily reduced until achieving those levels designed for growing feed on the $22^{\text {nd }}$ day. And so on until the $42^{\text {nd }}$ day.

Feed Composition: In order to achieve the nutritional and energetic levels, sufficient feed amount of each of 
Silveira MM, Martins JMS, Litz F, Carvalho CMC, Moraes CA, Silva MCA, Fernandes EA
Effect of Sorghum Based Nutritional Programs on Performance, Carcass Yield and Composition of Breast in Broilers the four nutritional stages were produced, according to each life day of life and within each expected nutritional levels (Figure 1). It was mixed up, with the aid of a horizontal feed mixer, different amounts of pre-starter and starter feed for the first eight days. Different amounts of starter and grower feed were mixed for the next 12 days and so on until the last day.

In the every three day nutritional adjustment program treatment ( 3 days WS), the same procedure of the daily treatment WS was performed, but the energetic and nutritional levels, as well as feed composition coincided with the same values and inclusions of each three days of the daily treatment.

\section{Experimental Management}

The experimental open house had it's environment controlled, with the aid of fans and nebulizers. The pens were equipped with a tubular feeder and a pendulum drinker. The lighting program was provided 24 hours a day, and the birds received ad libitum feed and drinking water throughout the 42 experimental days.

\section{STUDIED VARIABLES}

\section{Performance}

The cumulative performance was evaluated at the birds 7,21 , and 42 days of age. In this regard, the birds and feed weekly weighing were conducted; and the number and weight of dead birds were recorded daily to analyze the feed conversion. The studied variables were: average feed intake (FI), average weight gain $(W G)$, feed conversion (FC), and viability (V).

The average feed intake was obtained by the weight difference between the offered and the remained feed of each day, tree days or week period, divided by the number of birds in the period. The weight gain was determined by the weight difference of the live birds from each pen at the end of each week period in relation to the initial weight. For feed conversion, it was considered the weight of dead birds, adding to live weight and still reducing the weight of the oneday-old chicks housed. The viability was calculated as a percentage of the surviving birds in relation to the initial number of birds housed.

\section{Carcass yield}

At 42 days, all birds of each treatment, within the replication, were weighed with the Ramuza DP300 model scale (50 grams of accuracy) in groups separated by sex, being determined the average live weight. Then, a new weighing was performed individually for the identification of males and females which showed live weight the same as average weight $( \pm 5 \%)$ in their respective treatments. They were identified by a ring affixed to the leg, separated in pens, and noted in forms for the identification of the seal number and live weight.

These birds were subjected to fasting for 12 hours and at the $43^{\text {rd }}$ day, 10 birds per treatment $(5$ males and 5 females) were sent to slaughtering, a total of 40 birds were used for carcass yield analysis. At the slaughterhouse the birds were euthanized and stunned by electrical stunning and exsanguination by cutting the jugular vein, respectively. They were plucked, eviscerated and had the cuts made, which were weighed in a Balmak M25 scale (5 grams of accuracy) to determine carcass yield and cuts: eviscerated carcass (without feet, head and neck); breast (full- with skin and bone; deboned - breast without skin and bone); thighs/ drumsticks and wings. The carcass yield was expressed as the percentage of live weight and the cuts yields were expressed as the percentage of carcass eviscerated without feet, head and neck weight.

\section{Pectoral muscle chemical composition}

The breast cuts after weighing were placed in labeled plastic bags, sent to the LAMRA where they were stored at $-20^{\circ} \mathrm{C}$ for further percent composition evaluation. In the laboratory, samples were ground in a model CFP-22L electric meat grinder, homogenized and a portion of $200 \mathrm{~g}$ were placed on aluminum trays and subsequently pre-dried in a forced ventilation oven at $65^{\circ} \mathrm{C}$ for 96 hours, as described by Silva \& Queiroz (2002).

Analysis of dry matter, ether extract and crude protein were performed. The dry matter was determined by the gravimetric method, with heat usage, basing on the weight loss of the material subjected to heating at $105^{\circ} \mathrm{C}$, until constant weight. For the ether extract (lipid), the "Soxhlet" (gravimetric) method was used, basing on the amount of solubilized material by solvent. The protein fraction was determined by the "Kjeldahl" method which consists in determination of the total percentage of nitrogen, correct by factor 6.25. The methodologies were performed as described by Silva \& Queiroz (2002). All analyzes were performed in duplicate.

\section{Statistical analysis}

After checking the variances homogeneity and data residuals normality, they were subjected to variance analysis with $5 \%$ significance level, using Tukey test 
Silveira MM, Martins JMS, Litz F, Carvalho CMC, Moraes CA, Silva MCA, Fernandes EA
Effect of Sorghum Based Nutritional Programs on Performance, Carcass Yield and Composition of Breast in Broilers to compare means, through the SAS 9.3 software (SAS, 2011). For the variables carcass yield and breast composition, a factorial design $(4 \times 2)$ was used, four treatments and two genders.

\section{RESULTS AND DISCUSSION}

Significant differences were seen in feed consumption at 7,21 , and 42 days (Table 2 ). On the $7^{\text {th }}$ day the lowest intakes were obtained by daily (Daily WS) and every 3 day ( 3 days WS) nutritional programs. On the $21^{\text {st }}$ a lower intake was observed for the Daily WS, followed by the 3 days WS, which was similar to the four nutritional stages program with ground sorghum (4 stages GS). On the $42^{\text {nd }}$ day, the highest feed intake was observed in the four nutritional stages program with ground sorghum (4 stages WS) and the consumption in daily, every 3 day and 4 stages GS were statistically equal.

The Daily WS and 3 days WS nutritional programs had the lowest feed consumption, which can be explained by the better reaching to broilers energy and nutrient requirements levels. These results differ from Fernandes et al. (2013) evaluating broilers performance with diets based on whole and ground sorghum found that feed intake at 42 days old was not affected by the sorghum particle size.

On the $7^{\text {th }}$ day, the greatest weight gain was observed in 3 days WS, 4 stages WS and 4 stages GS nutritional programs (Table 2). On the $21^{\text {st }}$ day, 4 stages GS showed the greatest weight gain. However, on the $42^{\text {nd }}$ day, the cumulative weight gain did not differ ( $p>0.05$ ) between treatments. Similarly, Silva et al. (2015) evaluated the effect of the whole tanninfree grain sorghum replacing corn on the performance of broilers and nutritional program in four stages, concluded that the live weight at 42 days old between treatments with whole or ground sorghum did not differ. Therefore, in daily and every 3 days nutritional programs obtained the lowest feed intake and the same final live weight, showing that nutritional levels daily adjusted led to better performance.

On the $7^{\text {th }}$ day, the lowest feed conversion was observed in the Daily WS nutritional program (Table 2). On the $21^{\text {st }}$ day, the treatments had the same conversion. On the $42^{\text {nd }}$ day, the lowest conversions were obtained in the Daily WS and 3 days WS nutritional programs. These results were already expected, as these programs had the lowest feed consumption. The 4 stages GS nutritional program on the $42^{\text {nd }}$ day showed lower feed conversion than the 4 stages WS. These results differ from Fernandes et al. (2013), who observed that the feed conversion at 42 days old was not affected by the sorghum particle size.

Thus, equalized diets suits the requirements of broilers, reducing consumption and feed conversion, this is due to the supply of the daily nutritional requirements, resulting in more efficient use of nutrients. With the phases diet this is not possible, because since the beginning of the phase the chickens receive diets with sub-optimal level of nutrients and in the end receive in excess.

Table 2 - Performance of commercial line Hubbard Flex broilers at 7, 21 and 42 days of age, under different nutritional programs.

\begin{tabular}{|c|c|c|c|c|c|c|}
\hline \multirow{2}{*}{ Parameters } & \multicolumn{4}{|c|}{ Treatments } & \multirow[b]{2}{*}{$p$-value } & \multirow[b]{2}{*}{$\mathrm{CV}(\%$} \\
\hline & Daily WS & 3 days WS & 4 stages WS & 4 stages GS & & \\
\hline \multicolumn{7}{|c|}{ Feed intake (g) } \\
\hline 7 & $0.123 b$ & $0.132 b$ & $0.144 a$ & $0.144 \mathrm{a}$ & $<0.0001$ & 8.37 \\
\hline 21 & $1.163 c$ & $1.185 b$ & $1.232 \mathrm{a}$ & $1.224 a b$ & 0.0003 & 3.69 \\
\hline 42 & $4.524 b$ & $4.510 \mathrm{~b}$ & $4.800 \mathrm{a}$ & $4.574 b$ & 0.0006 & 4.04 \\
\hline \multicolumn{7}{|c|}{ Weight gain (g) } \\
\hline 7 & $0.158 b$ & $0.162 \mathrm{ab}$ & $0.165 a$ & $0.161 \mathrm{ab}$ & 0.0120 & 3.06 \\
\hline 21 & $0.933 b$ & 0.959 b & $0.959 b$ & $0.997 \mathrm{a}$ & $<0.0001$ & 3.30 \\
\hline 42 & 2.880 & 2.876 & 2.885 & 2.860 & 0.8255 & 2.03 \\
\hline \multicolumn{7}{|c|}{ Feed conversion (g/g) } \\
\hline 7 & $1.078 \mathrm{c}$ & $1.109 \mathrm{~b}$ & $1.174 a b$ & $1.199 \mathrm{a}$ & 0.0002 & 6.37 \\
\hline 21 & 1.307 & 1.294 & 1.341 & 1.285 & 0.0995 & 3.95 \\
\hline 42 & $1.564 \mathrm{c}$ & $1.564 \mathrm{C}$ & $1.656 \mathrm{a}$ & $1.605 b$ & $<0.0001$ & 2.91 \\
\hline \multicolumn{7}{|l|}{ Viability (\%) } \\
\hline 7 & 99.41 & 99.71 & 98.37 & 99.67 & 0.1529 & 1.45 \\
\hline 21 & 99.12 & 99.12 & 97.06 & 99.67 & 0.0779 & 2.36 \\
\hline 42 & 95.88 & 96.18 & 93.79 & 97.71 & 0.1380 & 3.74 \\
\hline
\end{tabular}

Means followed by different letters in the line differ by Tukey test $5 \%(p<0.05)$; WS (whole sorghum); GS (ground sorghum). 
Silveira MM, Martins JMS, Litz F, Carvalho CMC, Moraes CA, Silva MCA, Fernandes EA

\section{Effect of Sorghum Based Nutritional Programs on Performance, Carcass Yield and Composition of Breast in Broilers}

Females had lower dry matter and crude protein content and higher fat content in the pectoral muscle compared to males (Table 4). Normally, a decrease in muscle protein is followed by lipid increase (Le Bihan-Duval et al., 1998). The female broilers usually accumulate a larger amount of body fat (Stringhini et al. 2003). This occurs due to the presence of hormones and increased metabolism presented by males. Moreover, in the final phase, the proportion of fat accumulated by females was always greater than males, regardless of the diet energy level used.

In the treatment factor (Table 4), the daily nutritional program showed the lowest dry matter content, the other treatments were statistically equal in all composition parameters analyzed. The breast muscle amount of proteins and lipids are influenced by genetic and non-genetic factors (Bogosavljevi-Bošković et al., 2010). Nutrition is the external factor with the greatest influence on the chemical composition of broiler's meat (Marcu et al., 2013).

The bromatological composition of pectoral muscle is an important quality element for this type of meat (Bogosavljevi-Bošković et al., 2010). For the chemical components of the breast muscle, some authors reported values above $22.50 \%$ for total protein and lower than 3\% for fat content (Suchy et al, 2002; Marcu et al., 2009). Therefore, the results of all treatments are within this expected range, since the lower total protein content was $23.39 \%$ and higher lipid content was $2.68 \%$.

\section{CONCLUSION}

It is concluded that when using grain whole sorghum in broiler feed, the feed formulation programs involving daily or every three days nutritional adjustments showed better feed conversion and the not affect these cuts yields.

Table 3 - Percentual yield eviscerated carcass (without feet, head and neck), full breasts (with skin and bone), boneless breast, thighs/ drumsticks and wings of male and female broilers from Hubbard Flex line at 42 days old subjected to different nutritional programs.

\begin{tabular}{|c|c|c|c|c|c|c|}
\hline & $4 \times 2$ & Carcass yield & Full breast & Deboned breast & Thigh/ drumsticks & Wings \\
\hline \multirow{4}{*}{ Treatments } & Daily WS & 72.34 & $29.32 b$ & $22.05 \mathrm{~b}$ & 26.61 & 9.59 \\
\hline & 3 days WS & 72.14 & $29.25 b$ & $22.72 \mathrm{ab}$ & 25.97 & 9.71 \\
\hline & 4 stages WS & 73.33 & $30.56 a b$ & $23.18 a b$ & 26.24 & 9.55 \\
\hline & 4 stages GS & 73.36 & 31.68 a & $24.16 \mathrm{a}$ & 25.97 & 9.45 \\
\hline \multirow{2}{*}{ Sex } & Males & 72.86 & 29.85 & 22.91 & 26.36 & $9.23 b$ \\
\hline & Females & 72.73 & 30.55 & 23.14 & 26.03 & $9.92 \mathrm{a}$ \\
\hline \multirow[t]{2}{*}{ CV(\%) } & & 1.53 & 4.77 & 5.98 & 3.51 & 7,06 \\
\hline & Treatments & 0.0319 & 0.0016 & 0.0136 & 0.3766 & 0,8589 \\
\hline \multirow[t]{2}{*}{ p-value } & Sex & 0.7049 & 0.1360 & 0.5970 & 0.2615 & 0,0031 \\
\hline & Interaction & 0.4652 & 0.4227 & 0.5610 & 0.2408 & 0,2657 \\
\hline
\end{tabular}

Means followed by different letters in the line differ by Tukey test $5 \%(p<0.05)$; WS (whole sorghum); GS (ground sorghum). 
Table 4 - Bromatological composition of the pectoral muscle of male and female broilers from Hubbard Flex line at 42 days old subjected to different nutritional programs.

\begin{tabular}{|c|c|c|c|c|}
\hline & $4 \times 2$ & Dry Matter & Ether Extract & Crude Protein \\
\hline \multirow{4}{*}{ Treatments } & Daily WS & $27.51 \mathrm{~b}$ & 2.60 & 23.66 \\
\hline & 3 days WS & $27.85 a$ & 2.67 & 23.60 \\
\hline & 4 stages WS & $27.91 \mathrm{a}$ & 2.68 & 23.47 \\
\hline & 4 stages GS & $27.96 \mathrm{a}$ & 2.68 & 23.39 \\
\hline \multirow{2}{*}{ Sex } & Male & $28.31 \mathrm{a}$ & $2.56 \mathrm{~b}$ & $23.97 \mathrm{a}$ \\
\hline & Female & $27.26 \mathrm{~b}$ & $2.72 \mathrm{a}$ & $23.08 b$ \\
\hline \multirow[t]{2}{*}{$\mathrm{CV}(\%)$} & & 1.78 & 3.78 & 1.55 \\
\hline & Treatment & 0.0002 & 0.0583 & 0.3635 \\
\hline \multirow[t]{2}{*}{$p$-value } & Sex & 0.0000 & 0.0001 & 0.0000 \\
\hline & Interaction & 0.1112 & 0.9874 & 0.0865 \\
\hline
\end{tabular}

Means followed by different letters in the line differ by Tukey test $5 \%$ ( $p<0.05)$; WS (whole sorghum); GS (ground sorghum).

same results in weight gain, carcass and commercial cut yields and breast composition comparing to 4 stages nutritional program. Thus, daily feed programs could be performed in poultry industry with the mixture of sorghum grains and concentrates directly on farms contributing to better logistics and feed transportation costs.

\section{REFERENCES}

Assuena V, Filardi RS, Junqueira OM, Casartelli EM, Laurentiz AC, Duarte KF. Replacement of maize by sorghum in laying hens diets formulated to attempt different criteria in amino acid requirements. Ciência Animal Brasileira 2008;9(1):93-99.

Bogosavljevi-Bošković S, Pavlovskić Z, Petrović MD, Dosković V, Rakonjac S. Broiler meat quality:Proteins and lipids of muscle tissue-review. African Journal of Biotechnology 2010;9(54):9177-9182.

Buteri CB. Efeitos de diferentes planos nutricionais sobre a composição e o desempenho produtivo e econômico de frangos de corte [tese]. Viçosa (MG): Universidade Federal de Viçosa; 2003. 151p.

Carolino ACXG, Silva MCA, Litz FH, Fagundes NS, Fernandes EA. Performance and carcass composition of broiler chickens fed diets containing whole grain sorghum. Bioscience Journal 2014;30(4):11391148.

Dozier WA. Reducing utility cost in the feed mill. Watt Poultry USA 2002;53:40-44.

Fernandes EA, Marcacine BA, Tesini JRM. Substituição do milho por sorgo com e sem adição de enzimas em rações para frangos de corte. Anais da Conferência Apinco de Ciência e Tecnologia Avícolas; 2002; Campinas: FACTA; 2002. p.34.

Fernandes EA, Pereira WJS, Hackenhaar L, Rodrigues RM, Terra R. The use of whole grain sorghum in broiler feeds. Brazilian Journal of Poultry Science 2013;15(3):217-222

Garcia RG, Mendes AA, Costa C, Paz ICLA, Takahashi SE, Pelícia KP, et al. Effects on performance and meat quality of replacing corn with sorghum in a broiler diet. Arquivo Brasileiro Medicina Veterinária e Zootecnia 2005;57(5):634-643.

Garcia RG, Mendes AA, Paz ICLA, Komiyama CM, Caldara FR, Nääs IA, et al. Implications of the use of sorghum in broiler production. Brasilian Journal of Poultry Science 2013;15(3):257-262.
Le Bihan-Duval EL, Mignon-Grasteau S, Millet N, Beaumont C. Genetic analysis of a selection experiment on increased body weight and breast muscle weight as well as on limited abdominal fat weight. British Journal of Nutrition 1998;39(3):346-353.

MacLeod M. Nutrition-related opportunities and challenges of alternative poultry production systems. Lohmann information 2013;48(2):23-28.

Marcu A, Vacaru-Opriş I, Marcu A. The influence of feed protein and energy level on meat chemical composition from different anatomical regions at "Cobb 500" hybrid. Scientific Papers Animal Science and Biotechnology Timisoara 2009;42(1):147-150.

Marcu A, Vacaru-Opris I, Dumitrescu G, Marcu A, Ciochinã LP, Nicula M, et al. Effect of diets with different energy and protein leves on breast muscle characteristics of broiler chickens. Scientific Papers Animal Science and Biotechnologies 2013;46(1):333-340.

Moreno JO, Espíndola GB, Santos MSV, Freitas ER, Gadelha AC, Silva FMC. Performance and egg quality of laying hens fed diets with sorghum and paprika replacing corn. Acta Scientiarum Animal Sciences 2007;29(2):159-163.

Moura AMA, Fonseca JB, Rabello CBV, Takata FN, Oliveira NTE. Performance and egg quality of laying Japanese quails fed rations with different sorghum levels. Revista Brasileira de Zootecnia 2010;39(12):26972702.

Picard M, Melcion JP, Bertrand D, Faure JM. Visual and tactile cues perceived by chickens. In: McNab JM; Boorman KN, editors. Poultry feedstuffs: supply, composition and nutritive value. Wallingford: Poultry Science Symposium; 2002. p.279-300.

Rocha VRRA, Dutra Júnior WM, Rabello CBV, Ramalho RP, Ludke MCMM, Silva EC. Total replacement of corn by sorghum and slaughterhouse poultry oil in broiler diets. Revista Brasileira de Zootecnia 2008;(37):95102.

Rostagno HS, Büzen S, Sakomura NK, Albino LFT. Methodological improvements in feedstuffs evaluation and nutritional requirements for poultry and swine. Revista Brasileira de Zootecnia 2007;36:295-304.

Rostagno HS, Albino LFT, Donzele JL. Tabelas brasileiras para aves e suínos: composição de alimentos e exigências nutricionais. Viçosa: UFV; 2011. $251 \mathrm{p}$.

Sakomura NK, Rostagno HS. Métodos de pesquisa em nutrição de monogástricos. Jaboticabal: Funep; 2007. 283p.

Santos ALS, Gomes AVC, Pessôa MF, Mastafá S, Araújo AHB, Vieira AA. Chemical composition and energetic values of proteic sources in meat quails at different ages. Ciência Rural 2006;36(3):930-935. 
Silveira MM, Martins JMS, Litz F, Carvalho CMC, Moraes CA, Silva MCA, Fernandes EA

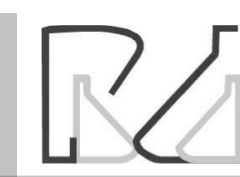

Effect of Sorghum Based Nutritional Programs on Performance, Carcass Yield and Composition of Breast in Broilers
SAS - Statical Analysis System. Statistical analysis system: user's guide:statistics. Version 9.3. Cary: SAS Institute; 2011

Silva DJ, Queiroz AC. Análise de alimentos (métodos químicos e biológicos). 3.ed. Viçosa:UFV; 2002. 235 p

Silva MCA, Carolino ACXG, Litz FH, Fagundes NS, Fernandes EA, Mendonça GA. Effects of sorghum on broilers gastrointestinal tract. Brazilian Journal of Poultry Science 2015;17(1):95-102.

Stringhini JH, Laboissiére M, Muramatsu K, Leandro NSM, Café MB. Performance and Carcass Yield of Four Broiler Strains Raised in Goiás, Brazil. Revista Brasileira de Zootecnia 2003;32(1):183-190.
Suchy $P$, Jelínek $P$, Straková $E$, Hucl J. Chemical composition of muscles of hybrid-broiler chickens during prolonged feeding. Czech Journal of Animal Science 2002;47(12):511-518.

Tavernari FC, Buteri CB, Rostagno HS, Albino LFT. Requirements of lysine, nutritional plans and mathematical models for determination of the requirements of broilers. Acta Veterinária Brasílica 2009;3(2):48-61.

Xu Y, Stark CR, Ferket PR, Williams CM, Brake J. Effects of feed form and dietary coarse ground corn on broiler live performance, body weight uniformity, relative gizzard weight, excreta nitrogen, and particle size preference behaviors. Poultry Science 2015;94(7):1549-1556. 